\title{
アミノ酸シグナルによる骨格維持機構
}

\author{
宝田剛 志
}

\section{Regulatory Mechanisms of Skeletal Tissues by Amino Acid Signaling}

\author{
Takeshi Takarada \\ Laboratory of Molecular Pharmacology, Division of Pharmaceutical Sciences, Kanazawa University Graduate \\ School of Natural Science and Technology; Kakuma-machi, Kanazawa 920-1192, Japan.
}

(Received February 25, 2013)

\begin{abstract}
In this review, we would outline the possible signaling system for three types of amino acids including glutamate (Glu) , $\gamma$-aminobutyric acid (GABA) and D-serine (D-Ser) to play a role as an extracellular signal mediator in mechanisms underlying maintenance of the cellular homeostasis in skeletal tissues. Although Glu and GABA has been thought to be an excitatory/inhibitory amino acid neurotransmitter in the mammalian central nervous system, our molecular biological analyses give rise to a novel function for Glu and GABA as an autocrine and/or paracrine factor in three types of distinct cell types including osteoblasts, osteoclasts and chondrocytes in bone tissues. Moreover, D-Ser plays a pivotal role in osteoclastogenesis through a mechanism related to the incorporation of serine enantiomers in osteoclasts after the synthesis and subsequent release from adjacent osteoblasts. Accordingly, bone formation and maintenance seems to be under control by amino acid signaling in skeletal tissues as seen with neurotransmission in the brain.
\end{abstract}

Key words_-bone; cartilage; glutamate; $\gamma$-aminobutyric acid (GABA); D-serine

\section{1. はじめに}

骨格系は，脊椎動物の最も基本的な特徵であり， 生体の支持や運動機能の維持に必須の役割を果たす が，同時に生体のカルシウムイオン貯蔵庫としてそ の血中濃度維持にも不可欠である。骨組織では，破 骨細胞，骨芽細胞及び軟骨細胞を中心に様々な細胞 が密接して存在するが, このように多様な細胞が集 合する組織においては, 細胞同士の協調が組織機能 の発現と維持に必須なので, 細胞間連絡を担う情報 伝達物質の役割が非常に重要であると考えられる. よって，これらの細胞に対して特異的に作用する物 質を新たに特定することは, 各細胞の分化・成熟・ 機能の制御機構解明に留まらず, それぞれの細胞機 能異常に関連する疾患の予防や治療に対し, 極めて 重要な意義を持つと推察される。現在のところ, 骨 格組織の機能維持には, 各種のホルモンやサイトカ インを介する細胞間ネットワーク機構が深く関与す

The author declares no conflict of interest.

金沢大学医薬保健研究域薬学系薬物学研究室 (T9201192 金沢市角間町)

e-mail: takarada@p.kanazawa-u.ac.jp

本総説は, 平成 25 年度日本薬学会奨励賞の受賞を記念

して記述したものである.
る事実が解明されている.

一方，アミノ酸はエネルギー産生やタンパク質合 成に関与し，生体中ではすべての組織や細胞におい て，極めて重要かつ基本的な物質であることは周知 の事実である、筆者らは，生体内に存在するアミノ 酸類の中でも特に 3 種類のアミノ酸, グルタミン酸, $\gamma$-アミノ酪酸及び D-セリンのような脳内での情報 伝達物質が, 骨格組織でのシグナル伝達分子として 積極的に働くことを発見し，「アミノ酸による骨格 維持制御機構」という，骨組織にとつて革新的な概 念を世界に先駆けて提唱した。その詳細は以下の通 りである.

\section{2. グルタミン酸による骨格維持制御機構}

グルタミン酸（L-glutamate; Glu）は中枢神経系 において興奮性神経伝達物質として働くアミノ酸で あり，細胞膜上の Glu receptor（GluR）を介して 細胞内に興奮性の情報を伝達することが知られてい る. Glu が情報伝達物質として機能するためには, 各種 Glu シグナル装置が必要であるが，シグナル 入力系としての GluR, シグナル出力系としての vesicular glutamate transporter (VGLUT) 及びシグナ ル終止系としての glutamate transporter（GluT）で 
ある excitatory amino acid transporter (EAAT) が 必須であるとされている。 また EAAT 以外の GluT として Cystine/Glu antiporter が同定されており， Cystine と Glu の交換輸送を行うことにより，細胞 内 glutathione（GSH）合成に必須の役割を果たす ことが知られている．筆者らは，骨芽細胞のモデル 細胞として MC3T3-E1 細胞及びマウス頭蓋骨由来 初代培養骨芽細胞を使用して，骨芽細胞に発現する Cystine/Glu antiporter に Glu が作用すると，骨芽 細胞の増殖性が抑制されること, ${ }^{1)}$ 閉経後骨粗鬆症 モデルマウスの骨組織では，Cystine/Glu antiporter サブユニットの 1 つである xCT が高発現するこ と, ${ }^{2)}$ 及び骨芽細胞に xCT を強制発現させると骨芽 細胞の分化能が顕著に抑制されること息を見い出 した。また，間葉系幹細胞のモデル細胞として $\mathrm{C} 3 \mathrm{H} 10 \mathrm{~T} 1 / 2$ 細胞及びマウス骨髄由来間葉系幹細胞 を使用し解析を行つた。その結果，Glu が間葉系幹 細胞膜に発現する Cystine/Glu antiporter に作用す ることにより, 細胞内 GSH 濃度変動を介して幹細 胞の自己複製能4) 及び骨芽細胞への分化能を抑制す ること5)を見い出した。これらの実験的事実は, Glu シグナルネットワーク形成が骨芽細胞だけでは なく，その前駆細胞においても細胞機能制御に重要 である可能性を強く示唆する結果である.

\section{GABA による骨格維持制御機構}

中枢神経における神経情報伝達は，主に興奮性シ グナルと抑制性シグナルの相互調節により成り立つ ている．興奮性アミノ酸伝達物質としては上述の Glu が，及び抑制性アミノ酸伝達物質としては $\gamma$ アミノ酪酸（ $\gamma$-aminobutyric acid; GABA）がよく 知られている。 これら神経伝達物質を介する相反性 シグナル伝達調節により脳内の機能が制御されるこ とを考えると，末梢組織においても，興奮性の Glu シグナル伝達機構と，抑制性の GABA シグナル伝 達機構が随伴して存在する可能性が考えられる.

Glu シグナル研究の場合と同様に, MC3T3-E1 細 胞及びマウス初代培養骨芽細胞を利用した解析の結 果，骨芽細胞には GABA 受容体サブタイプの 1 つ である $\mathrm{GABA}_{\mathrm{B}}$ 受容体構成サブユニットとして，

$\mathrm{GABA}_{\mathrm{B}} \mathrm{R} 1$ サブユニットと $\mathrm{GABA}_{\mathrm{B}} \mathrm{R} 2$ サブユニッ トの両サブユニットが発現して， $\mathrm{GABA}_{\mathrm{B}}$ 受容体と して破骨細胞の分化決定因子である RANKL の発 現制御を通じて，骨リモデリングを制御する事実を

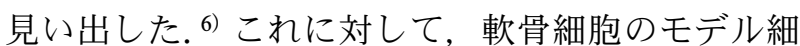
胞として ATDC5 細胞及びマウス肋軟骨由来初代培 養軟骨細胞を用いて解析したところ，軟骨細胞では $\mathrm{GABA}_{\mathrm{B}} \mathrm{R} 2$ サブユニットの発現が求められないにも かかわらず， $\mathrm{GABA}_{\mathrm{B}} \mathrm{R} 1$ サブユニットは細胞核内に おいて転写制御因子 ATF4 の機能調節を介して, 軟骨細胞の分化と成熟を正に制御することを見い出 した. ${ }^{7)} こ の$ 結果は， $\mathrm{GABA}_{\mathrm{B}}$ 受容体構成サブユニ ットが，単独で遺伝子転写に影響を与える可能性を 初めて提唱することとなった。

\section{D-セリンによる骨格維持制御機構}

D-セリン（D-Serine; D-Ser）は，L-Ser からラセ ミ化酵素である serine racemase（SR）により合成 される D 体アミノ酸である。中枢神経系を構成す る細胞群は主に神経細胞とグリア細胞であるが，グ リア細胞においては L-Ser は SR により D-Serへと 変換されるが，この D-Ser は神経細胞においては Glu 受容体の一種である NMDA 受容体の Glycine siteへの結合を介して，NMDA 受容体活性化に必 須の内在性アゴニストとして機能することが知られ ている.

筆者らは，ATDC5 細胞及びマウス肋軟骨由来初 代培養軟骨細胞を用いて解析したところ，軟骨細胞 には NMDA 受容体が発現し，その活性化は軟骨細

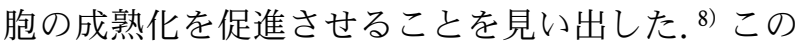
結果を受けてさらに解析を進めたところ，軟骨細胞 には D-Ser 合成酵素である SR が高発現すること, ${ }^{9}$ 軟骨細胞が D-Ser の合成及び放出活性をともに有 すること, ${ }^{9)}$ 及び軟骨細胞の NMDA 受容体が D-Ser による活性調節を受けることを発見した. ${ }^{10)}$ さらに, SR は軟骨細胞だけではなく骨芽細胞にも発現し て，骨芽細胞由来の D-Ser が破骨細胞に発現する アミノ酸トランスポーターに作用し， L-Ser の細胞 内輸送を抑制して破骨細胞による骨吸収を抑制する ことを見い出した. ${ }^{11)}$ 以上の研究成績は，骨芽細 胞，破骨細胞及び軟骨細胞のいずれにおいても， D-Ser が重要な内因性機能制御因子である可能性を 世界に先駆けて実証する内容である（Fig. 1).

\section{5. おわりに}

代表的な骨疾患である骨粗鬆症の日本における患 者数は, 現在 1000 万人を超えると推定されてい る。また軟骨破壊の起こる二大疾患は関節リウマチ と変形性関節症であるが，これら疾患に対する画期 
(A)

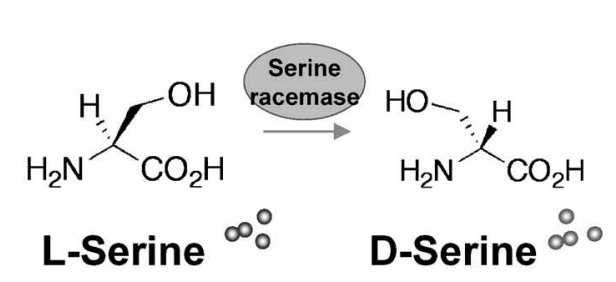

(B)

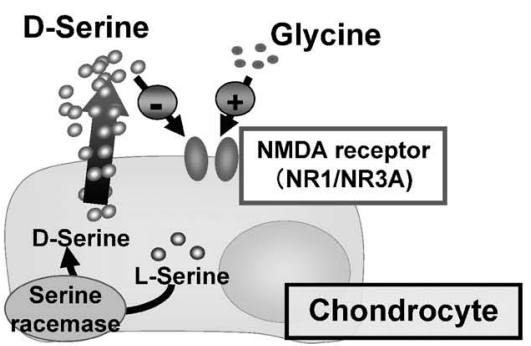

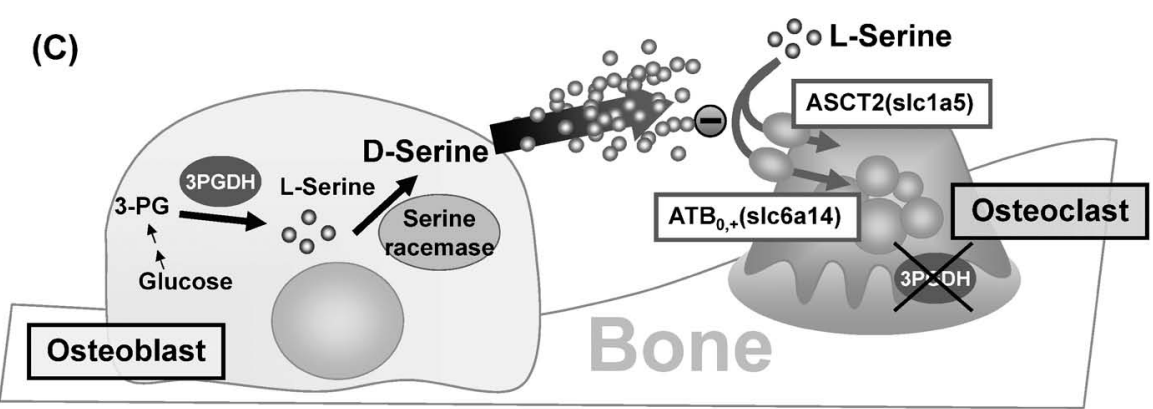

Fig. 1. D-Serine in Skeletal Tissues

(A) Structual diagram of L-serine and D-serine. (B) D-Ser would be synthesized from intracellular L-Ser by the catalytic action of SR expressed by chondrocytes at different developmental stages for subsequent release into extracellular space. Extracellular D-Ser could then inhibit as an antagonist for the Gly-operated NMDAR composed of NR1 and NR3A subunits expressed by hypertrophic chondrocytes, followed by interference with Runx2 transcriptional activity toward delayed chondrocyte differentiation. (C) D-Ser may play a pivotal role in osteoclastogenesis through a mechanism related to the incorporation mediated by both $\mathrm{ATB}_{0,+}$ and ASCT2 of serine enantiomers in osteoclasts after the synthesis and subsequent release from adjacent osteoblasts.

的な治療手段や治療薬は現在のところ皆無の状態で ある。この現状を勘案すると，両疾患に対する治療 戦略の展開は，世界的規模で社会的必要性と緊急性 を有する重大課題である。筆者らはアミノ酸による 骨格維持制御機構の存在に関する研究を現在も実施 中であるが, 12) 筆者らが解明した新たな分子基盤に 基づいて，骨関節系疾患に対する新規治療戦略の展 開が可能となると推察される。またわれわれは既に リウマチ性疾患の発症とアミノ酸シグナルとの関連 性について，全身性エリテマトーデス発症と NMDA 受容体機能異常との関連性を報告済夕であ る. 13) 今回明らかとした一連の研究成果は, 生体内 細胞間ネットワーク構築と維持メカニズムに新規概 念を導入するだけでなく, 薬物療法の実施が極めて 困難な骨格系疾患の治療と予防の確立に向けて，新 しい観点からの理論構築と実践的対策を可能とする ものと考えられる.

\section{謝辞本研究を遂行する上において終始ご懇切} なるご指導とご鞭撻を賜りました，金沢大学医薬保 健研究域薬学系・米田幸雄教授に厚く御礼申し上げ ます。また，本研究の遂行にあたり，ご指導とご鞭
撻を賜りました大阪府立大学大学院環境生命科学研 究科・中村洋一教授, 立命館大学薬学部 - 谷浦秀夫 教授, 京都産業大学総合生命科学部生命システム学 科・中村暢宏教授，セントルイス大学小児科・戸松 俊二博士，金沢大学医薬保健研究域薬学系・檜井栄 一准教授並びに金沢大学医薬保健研究域薬学系・中 道範隆准教授に厚くお礼申し上げます。さらに，多 大なるご協力とご援助を頂きました金沢大学医薬保 健研究域薬学系・薬物学研究室の皆様に深く感謝い たします。最後に, 日本薬学会奨励賞選考委員並び に関係者の先生方に深謝いたします。

\section{REFERENCES}

1) Uno K., Takarada T., Hinoi E., Yoneda Y., J. Cell. Physiol., 213, 105-114 (2007).

2) Uno K., Takarada T., Nakamura Y., Fujita H., Hinoi E., Yoneda Y., J. Pharmacol. Sci., 115, 309-319 (2011).

3) Uno K., Takarada T., Takarada-Iemata M., Nakamura Y., Fujita H., Hinoi E., Yoneda Y., J. Cell. Physiol., 226, 2953-2964 (2011).

4) Iemata M., Takarada T., Hinoi E., Taniura H., Yoneda Y., J. Cell. Physiol., 213, 721-729 
(2007).

5) Takarada-Iemata M., Takarada T., Nakamura Y., Nakatani E., Hori O., Yoneda Y., J. Cell. Physiol., 226, 652-665 (2011).

6) Takahata Y., Takarada T., Hinoi E., Nakamura Y., Fujita H., Yoneda Y., J. Biol. Chem., 286, 32906-32917 (2011).

7) Takahata Y., Hinoi E., Takarada T., Nakamura Y., Ogawa S., Yoneda Y., J. Biol. Chem., 287, 33293-33303 (2012).

8) Takahata Y., Takarada T., Osawa M., Hinoi E., Nakamura Y., Yoneda Y., Cell Tissue Res., 333, 91-103 (2008).

9) Takarada T., Hinoi E., Takahata Y., Yoneda
Y., J. Cell. Physiol., 215, 320-328 (2008) .

10) Takarada T., Takahata Y., Iemata M., Hinoi E., Uno K., Hirai T., Yamamoto T., Yoneda Y., J. Cell. Physiol., 220, 756-764 (2009).

11) Takarada T., Takarada-Iemata M., Takahata Y., Yamada D., Yamamoto T., Nakamura Y., Hinoi E., Yoneda Y., J. Cell. Physiol., 227, 3477-3487 (2012).

12) Takarada T., Yakugaku Zasshi, 132, 11451149 (2012).

13) Gono T., Takarada T., Fukumori R., Kawaguchi Y., Kaneko H., Hanaoka M., Katsumata Y., Yoneda Y., Yamanaka H., Arthritis Rheum., 63, 3952-3959 (2011). 